JOSAR, Vol. 1 No. 2 September, 2018; p-ISSN: 2502-8251; e-ISSN: 2503-1155

Copyrights@ Balitar Islamic University, Blitar-Indonesia https://ejournal.unisbablitar.ac.id/index.php/josar

\title{
FLIPBOOK MODULE AS A PRODUCT FOR DEVELOPMENT OF ANIMAL NETWORK MATERIAL MATERIALS FOR STUDENTS XI CLASS SCHOOL
}

\author{
Ariska Yuli Damayanti ${ }^{1}$, Maratus Sholihah², Dwi Kameluh ${ }^{3}$ \\ 1,2 Islamic University of Balitar; Jl. Majapahit No.04, Telp. (0342) 813145 \\ ${ }^{3}$ Biology education, FKIP Balitar Islamic university, Blitar \\ e-mail: ${ }^{* 1}$ Ariskayuli28@gmail.com,
}

\begin{abstract}
This research is research and development $(R \& D)$. the method used is $4 D$ consisting of 4 stages Define, Design, Develop, and Disseminate or adapted into a 4-P model, namely Defining, Designing, Developing, and Spreading.The results of the validation by the validator were $77.5 \%$ in the material aspects and $79.3 \%$ in the teaching material aspects, and $74.4 \%$ in the language aspects. In accordance with the module eligibility criteria that the Flipbook-based module is appropriate to use. The results of ANACOVA analysis showed the effect of Flipbook module teaching materials on student learning outcomes by $22.3 \%$. Based on the results of these studies it can be concluded that the Flipbook module can be said to be worthy of being used as a learning material to improve student learning outcomes.
\end{abstract}

Keywords: Research development, Flipbook based modules, Learning outcomes

\section{INTRODUCTION}

The 2013 Curriculum implementation is a curriculum that emphasizes student-centered learning to actively learn. Implementation of learning, the teacher acts as a facilitator of students in gaining knowledge. The implementation of this learning process is that there are additional hours of study so that the teacher has the flexibility of time to develop the learning process oriented towards active students learning. The efforts of the teacher in fulfilling his role as a student facilitator can be carried out by providing teaching materials, the provision of teaching materials is not only in the form of textbooks, the provision of teaching materials aims to help students gain an understanding of the material.

There are various types of teaching materials that can be chosen according to learning needs. Teaching materials are learning tools or tools that contain learning material, methods, boundaries, and ways of evaluating which are designed systematically and interestingly in order to achieve the expected goals, namely achieving competence or sub- 
JOSAR, Vol. 1 No. 2 September, 2018; p-ISSN: 2502-8251; e-ISSN: 2503-1155

Copyrights@ Balitar Islamic University, Blitar-Indonesia https://ejournal.unisbablitar.ac.id/index.php/josar

competence in all its complexity. One of them is teaching materials with forms modules. Modules are learning materials that are designed systematically based on a particular curriculum and are packaged in the form of the smallest learning units and allow them to be studied independently in a certain time unit. The independent learning process is in accordance with the characteristics of the 2013 curriculum, which is student-centered learning.

In accordance with interviews conducted with biology teachers, animal tissue material is usually carried out by practicum. Practicum can provide a real picture and can improve the skills of students. But, in doing practicum, it must be equipped with adequate facilities. Not all high school schools have adequate facilities for practicum. One way to overcome this problem is to make a module teaching material in which there are many images accompanied by video.

The development of Flipbook-based module teaching materials is supported by previous research conducted by Destiyana (2016) on "Development of Flipbook-Based Science Modules The Theme of Environmental Pollution as an Independent Learning Source for Class VII SMP / MTS Students". The results of the study indicate that the development of Flipbook-based module teaching materials is suitable to be used as learning material and is effective in improving the learning outcomes of class $\mathrm{X}$ students in Environmental Pollution material.

\section{RESEARCH METHODS}

The approach used in this study is quantitative and qualitative approaches. Quantitative data in the form of assessment scores from expert teams. Qualitative data in the form of advice and input from the expert team. The research design used was Research and Development ( $R$ \& D) with the Thiagarajan 4D development model, et al. Consisting of define, design, development without dissemination. 
JOSAR, Vol. 1 No. 2 September, 2018; p-ISSN: 2502-8251; e-ISSN: 2503-1155

Copyrights@ Balitar Islamic University, Blitar-Indonesia https://ejournal.unisbablitar.ac.id/index.php/josar

The research procedure begins with the stages of defining, designing, and developing. The defining stage is done to find out the needs in the learning process and products that are developed through front end analysis, student analysis, task analysis, analysis concept and formulating objectives. The design phase that is carried out is compiling the test, selecting the media, choosing the format and preparing the initial design of the product. The development stage is a process to produce a product that is feasible to use through validation by a team of experts.

The product can be used as a reference for independent student learning resources prepared based on 2013 curriculum-based rules. The resulting products are in the form of flipbooks that can be used such as reading printed books as usual. The products produced are equipped with questions to assess completeness in each sub-section. This is created using the help of Professional 3DFlip 3D software, CorelDraw X7, and Macromedia Flash 8, Form modules in the form of soft files. The parts in this module include Cover, preface, introduction, content standards include core competencies (KI), basic competencies (KD), and learning objectives, instructions for use, material and practice questions, assessment methods, glossaries, answer keys, bibliography.

Products that are deemed feasible by experts can be used for product testing. Product testing is done on a limited scale to determine student responses. The instruments in this study used expert validation questionnaire sheets, teacher response assessment sheets and student response sheets. Data analysis techniques in the form of qualitative and quantitative data. Qualitative data in the form of advice and input from experts. Quantitative data in the form of scores from expert teams, teacher ratings and student responses. The calculation of the assessment by the expert team and the assessment by the teacher uses the following 
formula:

$$
\begin{aligned}
& \mathrm{P}=\frac{\sum x}{\sum x i} \times 100 \% \\
& \text { Information } \\
& \mathrm{P} \quad=\text { Percentage sought } \\
& \sum x \quad=\text { The number of respondents answers } \\
& \sum x i \quad=\text { Ideal amount }
\end{aligned}
$$

The eligibility criteria from the validation sheet are filled in, then matched with reference to Table 1.

Table 1. Criteria for level of validity

\section{Percentage (\%) Validation Criteria}

\begin{tabular}{cr}
\hline $76-100$ & Very decent \\
$56-75$ & Worthy \\
$40-55$ & Less feasible \\
$0-39$ & Not feasible \\
\hline
\end{tabular}

(Source: Arikunto, 2012)

Student questionnaire response calculation uses the following formula

$$
P=\frac{n}{N} \times 100 \%
$$

Information:

$\mathrm{P}=$ Feasibility score.

$\mathrm{N}=$ Expected maximum score.

$\mathrm{n}=$ The maximum number of scores obtained

The results of the percentage of student responses are adjusted to the criteria in Table 2

Table 2. Criteria for percentage score assessment

\begin{tabular}{lc}
\hline \multicolumn{1}{c}{ Interval \% S } & Criteria \\
\hline $81,25 \%<$ skor $\leq 100 \%$ & Very good \\
$62,50 \%<$ skor $\leq 81,25 \%$ & Well \\
$43,75 \%<$ skor $\leq 62,50 \%$ & Not good \\
$25 \%<$ skor $\leq 43,75 \%$ & Not nice \\
\hline
\end{tabular}

(Source: Arikunto, 2012) 
JOSAR, Vol. 1 No. 2 September, 2018; p-ISSN: 2502-8251; e-ISSN: 2503-1155

Copyrights@ Balitar Islamic University, Blitar-Indonesia https://ejournal.unisbablitar.ac.id/index.php/josar

\section{RESULTS AND DISCUSSION}

The development of Flipbook-based module teaching materials on animal tissue material was validated by material experts, media experts and linguists. The results of expert validation are shown in Tables 3, 4 and 5. The results of teacher evaluations and student responses are shown in Tables 6 and 7.

Table 3. Results of material validation

\begin{tabular}{|c|c|c|c|c|c|c|c|c|c|}
\hline \multirow{2}{*}{$\begin{array}{c}\text { Assessment } \\
\text { Criteria }\end{array}$} & \multicolumn{8}{|c|}{ Assessment Score } & \multirow[t]{2}{*}{ Score } \\
\hline & 1 & 2 & 3 & 4 & 5 & 6 & 7 & 8 & \\
\hline Validator 1 & 5 & 5 & 4 & 4 & 4 & 4 & 5 & 4 & 35 \\
\hline Validator 2 & 3 & 3 & 3 & 3 & 3 & 3 & 3 & 3 & 24 \\
\hline Validator 3 & 4 & 4 & 5 & 4 & 4 & 5 & 4 & 4 & 34 \\
\hline \multicolumn{9}{|c|}{ Total Score } & 93 \\
\hline \multicolumn{9}{|c|}{ Maximum Score } & 120 \\
\hline \multirow{2}{*}{\multicolumn{9}{|c|}{$\begin{array}{c}\text { Percentage } \\
\text { Category }\end{array}$}} & $77,5 \%$ \\
\hline & & & & & & & & & Very Decent \\
\hline
\end{tabular}

Tabulations from material expert questionnaires obtained a score of $77.5 \%$ with information worthy of being used for classroom learning activities.

Table 4. Result of media expert validation

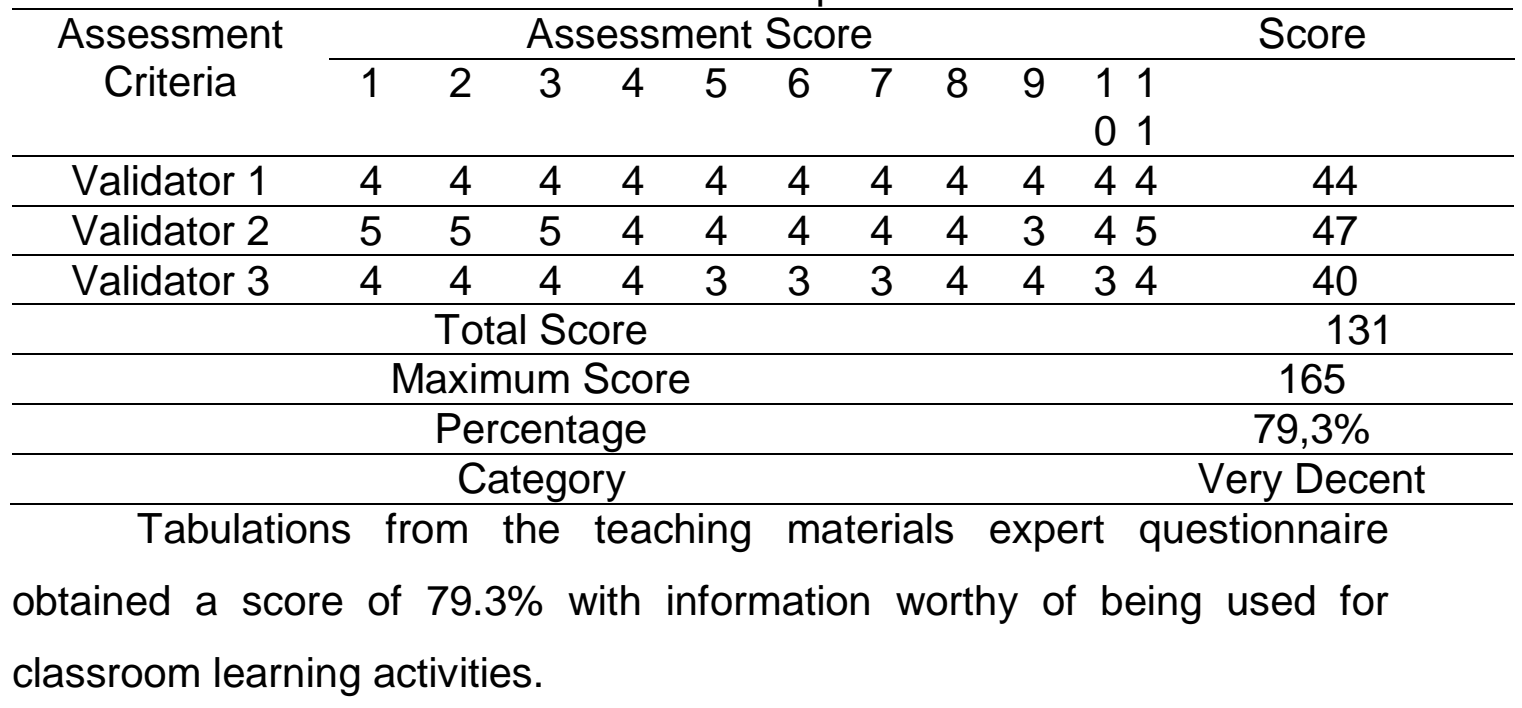


JOSAR, Vol. 1 No. 2 September, 2018; p-ISSN: 2502-8251; e-ISSN: 2503-1155

Copyrights@ Balitar Islamic University, Blitar-Indonesia https://ejournal.unisbablitar.ac.id/index.php/josar

Table 5. The results of the language expert's validation

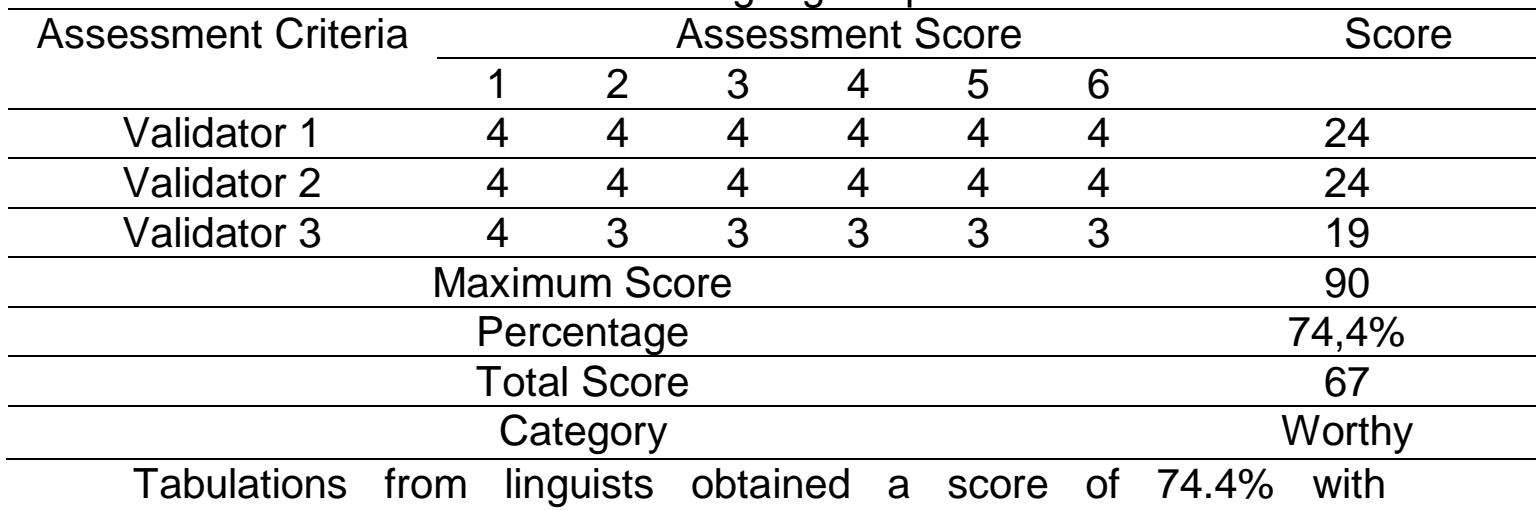

information worthy of use for learning activities in class.

Table 6. Teacher assessment results

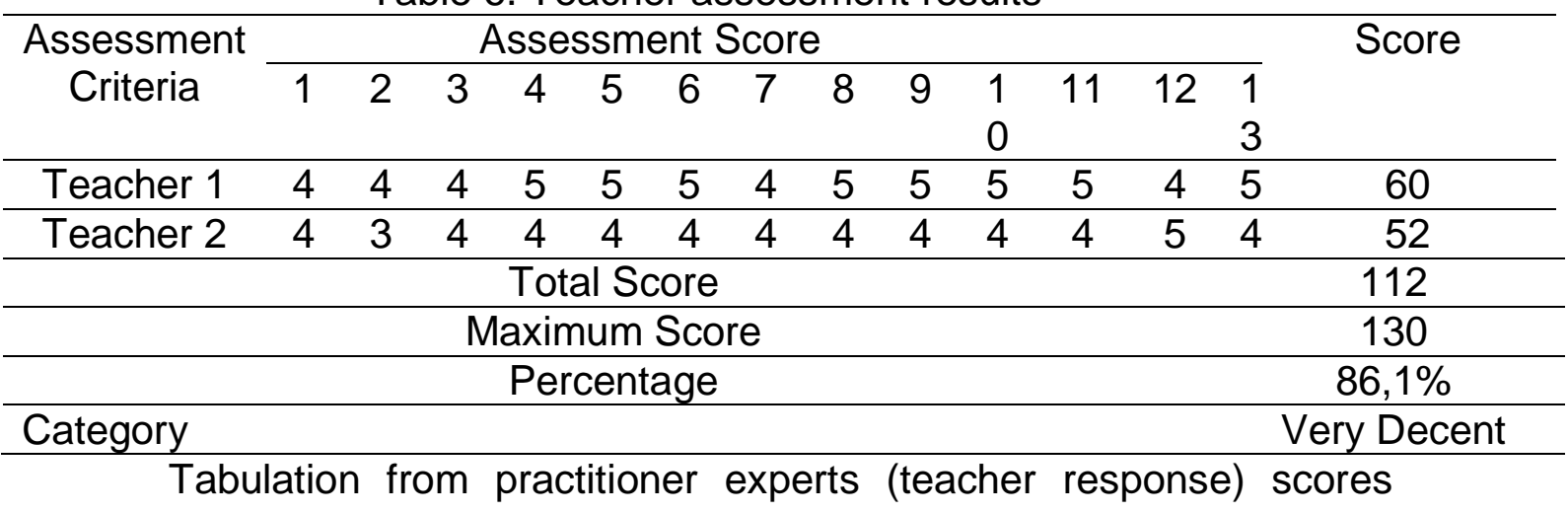

$86 \%$ with information that is very feasible to use for classroom learning activities. 
JOSAR, Vol. 1 No. 2 September, 2018; p-ISSN: 2502-8251; e-ISSN: 2503-1155

Copyrights@ Balitar Islamic University, Blitar-Indonesia https://ejournal.unisbablitar.ac.id/index.php/josar

Table 7. Readability test

\begin{tabular}{|c|c|c|c|c|c|c|c|c|c|c|c|c|c|}
\hline \multirow[b]{2}{*}{ No. } & \multirow[b]{2}{*}{ Name } & \multicolumn{11}{|c|}{ Statement } & \multirow[t]{2}{*}{ Score } \\
\hline & & 1 & 2 & 3 & $4 \quad 5$ & 6 & 78 & 9 & 10 & 11 & 12 & 13 & \\
\hline 1 & $\begin{array}{c}\text { students- } \\
1\end{array}$ & 3 & 4 & 4 & 34 & 3 & 34 & 4 & 3 & 4 & 3 & 4 & 46 \\
\hline 2 & $\begin{array}{c}\text { students } \\
-2\end{array}$ & 5 & 5 & 4 & 45 & 4 & 55 & 4 & 4 & 4 & 5 & 5 & 59 \\
\hline 3 & $\begin{array}{c}\text { students } \\
-3\end{array}$ & 4 & 4 & 4 & 45 & 4 & 54 & 4 & 4 & 3 & 4 & 3 & 52 \\
\hline 4 & $\begin{array}{c}\text { students } \\
-4\end{array}$ & 4 & 5 & 4 & 44 & 4 & 34 & 4 & 3 & 4 & 4 & 4 & 51 \\
\hline \multirow[t]{4}{*}{5} & $\begin{array}{c}\text { students } \\
-5\end{array}$ & 4 & 4 & 4 & 33 & 4 & $\begin{array}{ll}44 & 4\end{array}$ & 3 & 4 & 3 & 3 & 4 & 47 \\
\hline & & & & \multicolumn{9}{|c|}{ Total Score } & 204 \\
\hline & & & & \multicolumn{9}{|c|}{ Maximum Score } & 325 \\
\hline & & & \multicolumn{10}{|c|}{ Percentage } & $78,4 \%$ \\
\hline
\end{tabular}

Flipbook-based module teaching materials that have been developed by researchers have also been tested individually. The subjects of this individual test are students of class XI MIA 4 Blitar 4 Public High School totaling 5 students. Based on the readability questionnaire the Flipbookbased module scores $78.4 \%$.

Based on the results of expert validation, teacher assessment and student responses, Flipbook-based module teaching materials on animal tissue material are worthy of being used as learning materials. The assessment by material experts, teaching materials experts and linguists was $77.5 \%, 79.3 \%$ and $74.4 \%$ respectively. The average score of expert evaluations is $77 \% \%$ with very decent information. Assessment by the teacher obtained a score of $86.1 \%$ with very decent information. Students' responses in limited scale trials get a score of $78.4 \%$ with very good information. So that overall Flipbook-based module teaching materials in animal network material are used for classroom learning activities.

Product improvements are made to improve the products produced based on the shortcomings and weaknesses of the products produced. To 
JOSAR, Vol. 1 No. 2 September, 2018; p-ISSN: 2502-8251; e-ISSN: 2503-1155

Copyrights@ Balitar Islamic University, Blitar-Indonesia https://ejournal.unisbablitar.ac.id/index.php/josar

improve the population of Flipbook module teaching materials, animal tissue material is added with a manual for the use of Flipbook module teaching materials. The user guide to the use of teaching materials is made in three books, namely the user guide for students, teachers, and yourself.

\section{CONCLUSION}

Based on the results of the study, it was shown that the Flipbookbased module teaching material on animal tissue material was suitable to be used as learning material in the classroom. The feasibility of teaching materials is obtained from the expert's score with an average score of $77 \%$. Based on the teacher's response a score of $86.1 \%$ was obtained. While student responses obtained through a small group test on a limited scale get a score of $78.4 \%$.

\section{SUGGESTION}

Suggestions that can be given are that it is better at the development stage to do a re-validation test to get better results and are advised to develop until the disseminate stage.

\section{REFRENCES}

Arikunto. 2012. Basics of Educational Evaluation Edition 2. Jakarta: PT. Earth Literacy

Arsyat A. 2004. Learning Media. Jakarta: Rineka Cipta

Ministry of National Education. 2008. Module Writing. Ministry of National Education: Directorate of Education Personnel of the Directorate General of Quality Improvement of Educators and Education Personnel.

Wisdom. 2018. Development of Interactive Modules Based on Kvisoft Flipbook Maker Historical Class X High School Subjects Using the 4D Development Model. Thesis published. Jember. University of Jember. 
JOSAR, Vol. 1 No. 2 September, 2018; p-ISSN: 2502-8251; e-ISSN: 2503-1155

Copyrights@ Balitar Islamic University, Blitar-Indonesia https://ejournal.unisbablitar.ac.id/index.php/josar

Ministry of Education and Culture 2008. Development of Module Characteristics. Jakarta: Ministry of Education and Culture.

Kurniawan AD, Nurlalela L. 2013. Development of Student Books to Improve Learning Processes and Outcomes of Basic Competencies in Cornflake Cookies for Mentally Abused Students SMA-LB Negri

Gedangan Sidoarjo. Journal of the Faculty of Engineering Family Health Education Vol. 2, No.1, Hal. 6-17. Surabaya State University.

Prasetya TI. 2012. Increasing the Ability to Arrange Interactive Module Based Learning Outcome Instruments for Science Teachers of Magelang City Middle School. Journal of Educational Research and Evaluation of the Postgraduate Program Vol. 1, No. 2, p. 106-112 Semarang State University.

Prastowo, A. 2013. Development of Thematic Teaching Materials. Yogyajarta: Diva Press.

Prastowo, A. 2012. Kretaif's Guide to Making Innovative Learning Materials: Creating Interesting and Fun Learning Methods. Yogyakarta: Diva Press.

Rachmawati F, Urifa N, Wijayati A.2009. Biology for SMA / MA Class XI Science Program. BSE. Jakarta: Ministry of National Education.

Sugianto, et al. 2013. Virtual Module: Basic Digital Multimedia Flipbook Technique. Bandung FPTK. UPI.

Sugiyono. 2015. Research and Development Methods (R\&D) Bandung:Alfabeta. 